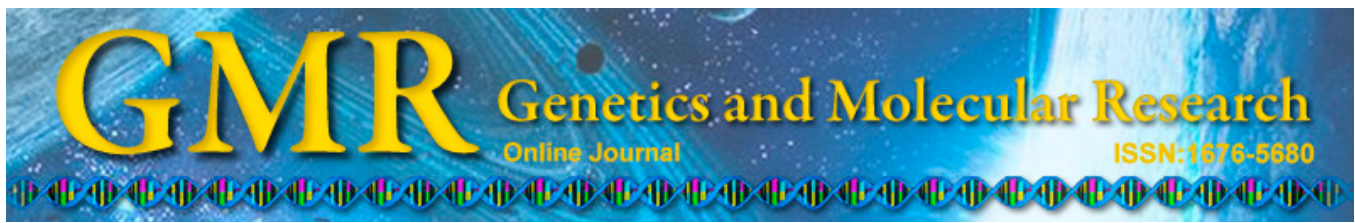

$\underline{\text { Research Note }}$

\title{
Characterization of microsatellite markers for the Restinga Antwren, Formicivora littoralis (Thamnophilidae), an endangered bird endemic to Brazil
}

\author{
F.G. Chaves ${ }^{1}$, M.B. Vecchi ${ }^{2}$, M.S. Webster ${ }^{3}$ and M.A.S. Alves ${ }^{2}$ \\ ${ }^{1}$ Programa de Pós-Graduação em Ecologia, \\ Instituto de Biologia Roberto Alcantara Gomes, \\ Universidade do Estado do Rio de Janeiro, Rio de Janeiro, RJ, Brasil \\ ${ }^{2}$ Departamento de Ecologia, Universidade do Estado do Rio de Janeiro, \\ Rio Janeiro, RJ, Brasil \\ ${ }^{3}$ Neurobiology and Behavior Department, Cornell Laboratory of Ornithology, \\ Cornell University, Ithaca, NY, USA
}

Corresponding authors: F.G. Chaves / M.A.S. Alves flaviagchaves@yahoo.com.br/masaal@globo.com

Genet. Mol. Res. 14 (3): 7986-7989 (2015)

Received October 13, 2014

Accepted March 11, 2015

Published July 17, 2015

DOI http://dx.doi.org/10.4238/2015.July.17.6

\begin{abstract}
Molecular markers are important tools in determining parentage, gene flow, and the genetic structure of species. In the case of rare, endemic, and/or threatened species, these markers can be used to understand key ecological questions and support conservation actions. We developed seven microsatellite markers for the only bird endemic to the Restinga ecosystem. Microsatellite loci were isolated from a library that was based on 10 individuals (six males and four females). Primers were tested in 107 individuals of the same population. The number of alleles per locus ranged from 4 to 19 , and the observed and expected heterozygosity varied from 0.15 to 0.84 and from 0.60 to
\end{abstract}


0.89 , respectively. We expect that the polymorphic microsatellite loci we describe will be useful for other studies, particularly in the Tropics.

Key words: Passeriformes; Primer; Multiplex; Parentage analysis; Restinga; Atlantic Forest

\section{INTRODUCTION}

Molecular data can elucidate the breeding dynamics of species. For example, parentage studies have revealed unexpected variations in reproductive success among individuals of socially monogamous species due to extra-pair fertilizations (Dowling et al., 2003). The Restinga Antwren was first described in 1990, and is considered the only bird endemic to Restinga (Gonzaga and Pacheco, 1990), an ecosystem (sandy plain and coastal vegetation) that is associated with the Atlantic Forest. The distribution of this bird is restricted to fragments of Restinga, in only seven municipalities of Rio de Janeiro State, Brazil. Due to habitat loss, the species is categorized globally as "Endangered" (IUCN, 2014) and "Critically Endangered" according to the Brazilian National Red List (Machado et al., 2008). Males and females differ in their plumage, are territorial, and are considered to be socially monogamous, tending to promiscuity (Chaves, 2014). Our aim was to develop microsatellite markers in order to access paternity data, and consequently to confirm the breeding system of this species.

\section{MATERIAL AND METHODS}

We extracted DNA from 10 blood samples (six males and four females) taken from a population in Praia do Vargas, Araruama, Rio de Janeiro State, Brazil $\left(22^{\circ} 56^{\prime} 21.9^{\prime \prime} \mathrm{S}, 42^{\circ} 17^{\prime} 58^{\prime}\right.$ 'W). The extraction protocol was the same as that described by Nicholls et al. (2000), for which we used a Qiagen DNeasy ${ }^{\circledR}$ Blood kit. Library construction, enrichment, and sequencing were conducted at the Cornell Life Sciences Core Laboratory Center, Cornell University, Ithaca, NY, USA. From the library, 32 microsatellite loci that appeared to be the most suitable for development were designed by Life Technologies, and 107 samples from different individuals were screened for allelic polymorphisms. A polymerase chain reaction (PCR) was conducted in a $10-\mu \mathrm{L}$ reaction volume, which consisted of $1 \mu \mathrm{L}$ DNA, $0.1 \mu \mathrm{L}$ JumpStart ${ }^{\mathrm{TM}} \mathrm{Taq}$ DNA polymerase $2.5 \mathrm{U} / \mu \mathrm{L}$ (Sigma. St. Louis MO, USA), $1.5 \mathrm{mM} \mathrm{MgCl}, 0.2 \mu \mathrm{L} \mathrm{mM} \mathrm{dNTPs}$ $(10 \mathrm{mM})$, and $10 \mu \mathrm{M}$ of each primer (the forward primer was fluorescence-labelled). The PCR conditions were as follows: $94^{\circ} \mathrm{C}$ for $2 \mathrm{~min}, 94^{\circ} \mathrm{C}$ for $30 \mathrm{~s}$, four cycles in which the temperature decreases (in each cycle) from $66^{\circ} \mathrm{C}$ to $50^{\circ} \mathrm{C}$ for $30 \mathrm{~s}$, increasing the temperature to $72^{\circ} \mathrm{C}$ for $1 \mathrm{~min}$, decreasing it to $50^{\circ} \mathrm{C}$ for 20 cycles to the annealing temperature, increasing it to $72^{\circ} \mathrm{C}$ for $10 \mathrm{~min}$, and finally decreasing it to $10^{\circ} \mathrm{C}$. For the genotyping, $1 \mu \mathrm{L}$ of the PCR product was mixed with $0.1 \mu \mathrm{L}$ LIZ $^{\circledR}$ Size Standard (Life Technologies Inc., Gaithersburg, MD, USA) and $11.9 \mu \mathrm{L}$ formamide. CERVUS (version 3.0.3) (Kalinowski et al., 2007) was used to determine the number of alleles $\left(N_{\mathrm{A}}\right)$ per locus, and the observed $\left(H_{\mathrm{O}}\right)$ and expected heterozygosity $\left(H_{\mathrm{E}}\right)$. Tests of significant deviations from the Hardy-Weinberg equilibrium were performed using GENEPOP (version 1.2) (Raymount and Rousset, 1995), and the frequency of null alleles was ascertained using ML-Relate (Kalinowski et al., 2006). 


\section{RESULTS AND DISCUSSION}

Of the 32 pairs of primers that were designed, seven were polymorphic. The number of alleles, the PCR product size, and the heterozygosity of each of these seven loci are shown in Table 1 . The $N_{\mathrm{A}}$ ranged from 4 to 19 , and the $H_{\mathrm{O}}$ and $H_{\mathrm{E}}$ ranged from 0.15 to 0.84 and 0.60 to 0.89 , respectively. Five loci (FoLi1, FoLi2, FoLi3, FoLi6, and FoLi7) exhibited significant deviations from the Hardy-Weinberg equilibrium $(\mathrm{P}<0.01)$, suggesting that there was a relatively high frequency of null alleles. These seven microsatellite loci were developed for parentage analyses, but they could be used to investigate population genetic structure and other analyses for the Restinga Antwren and other Neotropical species, particularly of the Thamnophilidae.

\begin{tabular}{|c|c|c|c|c|c|c|c|c|c|}
\hline Locus & Repeat motif & Primer sequence $\left(5^{\prime}-3^{\prime}\right)$ & $\mathrm{Ta}\left({ }^{\circ} \mathrm{C}\right)$ & {$\left[\mathrm{MgCl}_{2}\right]$} & $N_{\mathrm{A}}$ & $\mathrm{bp}$ & $H_{\mathrm{O}}$ & $H_{\mathrm{E}}$ & F null \\
\hline \multirow[t]{2}{*}{ FoLi1 } & $\mathrm{ACAT}_{(10)}$ & F:TAGGTCTCATAGGTAGGTAGGTG & & & & & & & \\
\hline & & R:AGTCTGAGTGTCATATTCCCAGG & 60 & 1.5 & 11 & $281-326$ & 0.58 & 0.75 & 0.22 \\
\hline \multirow[t]{2}{*}{ FoLi2 } & $\operatorname{AGAT}_{(9)}$ & F:TGCAGAATACCTCCCTGTACTAC & & & & & & & \\
\hline & & R:CAAATTGCATGACTCGATGTGTG & 60 & 1.5 & 13 & $201-256$ & 0.43 & 0.80 & 0.57 \\
\hline \multirow[t]{2}{*}{ FoLi3 } & $\mathrm{AGAT}_{(15)}$ & F:TATGGCAAGTTCCTTCTTTGACC & & & & & & & \\
\hline & & R:GCAGCCCAATAAACACCTCTATG & 60 & 1.5 & 16 & $232-252$ & 0.83 & 0.89 & 0.12 \\
\hline \multirow[t]{2}{*}{ FoLi4 } & $\mathrm{ACAT}_{(10)}$ & F:TCCCATAACTCACTAGAATCAGTG & & & & & & & \\
\hline & & R:CTCAAACCAAGACAGCTATGCAG & 60 & 1.5 & 19 & 293-313 & 0.48 & 0.74 & 0.03 \\
\hline \multirow[t]{2}{*}{ FoLi5 } & $\mathrm{AGAT}_{(15)}$ & F:ACCTTGTGTTAGCATAAATGAGTC & & & & & & & \\
\hline & & R:CACTTAGTGTCACTCCAAGCTAC & 60 & 1.5 & 4 & $200-240$ & 0.15 & 0.60 & 0.001 \\
\hline \multirow{2}{*}{ FoLi6 } & $\operatorname{ATCC}_{(20)}$ & F:GAACTGAATCTCTGCCCATTTCC & & & & & & & \\
\hline & & R:AGAGGGAGAGTCAGAGATTTCAC & 60 & 1.5 & 14 & 196-219 & 0.80 & 0.83 & 0.30 \\
\hline \multirow{2}{*}{ FoLi7 } & $\mathrm{AGAT}_{(12)}$ & F:CACCTGGACGCTTCTAATAAAGG & & & & & & & \\
\hline & & R:GGGTGAGTGGGTAGATGGATAG & 60 & 1.5 & 14 & $160-169$ & 0.84 & 0.87 & 0.057 \\
\hline
\end{tabular}

Ta, optimized annealing temperature; $\mathrm{MgCl}_{2}$, optimized concentration; $N_{\mathrm{A}}$, number of alleles; bp, pair-base; $H_{\mathrm{o}}$, observed heterozygosity; $H_{\mathrm{E}}$, expected heterozygosity; F null, quantity of null alleles.

\section{ACKNOWLEDGMENTS}

Research supported by the Conselho Nacional de Desenvolvimento Científico e Tecnológico (FGC Fellowship, \#148581/2010-2; MASA Grant, \#308792/2009-2), the Coordenação de Aperfeiçoamento de Pessoal de Nível Superior (FGC "Sandwich" Fellowship, \#1725212-1), and the Fundação de Amparo à Pesquisa do Estado do Rio de Janeiro (MASA Grant, \#E-26/102837/2012). We thank the Evolutionary Biology Laboratory at Cornell University, in particular Irby Lovette, Laura Stenzler, and Amanda Talaba, who helped with the analysis and infrastructure. We also thank Steven M. Bogdanowicz for assistance with the DNA library construction, Denise M. Nogueira for data interpretation, and colleagues from the Laboratório de Ecologia de Aves at Rio de Janeiro State University for field work.

\section{REFERENCES}

Chaves FG (2014). Territorialidade e ecologia reprodutiva de Formicivora littoralis (Aves: Thamnophilidae) na Restinga da Massambaba, RJ. Doctoral thesis, Instituto de Biologia Roberto Alcantara Gomes, Universidade do Estado do Rio de Janeiro

Dowling DK, Adcock GJ and Mulder RA (2003). Novel polymorphic microsatellite markers for paternity analysis in the red-capped robin (Petroica goodenovii: Aves). Mol. Ecol. Notes 3: 517-519. doi: 10.1046/j.471-8286.2003.00497.x

Gonzaga LP and Pacheco JF (1990). Two new subspecies of Formicivora serrana (Hellmayr) from southeastern Brazil, and notes on the type locality of Formicivora deluzae Ménétriés. Bull. Brit. Ornithol. 110: 187-193. 
IUCN (2014). Red List of Threatened Birds. http://www.iucn.org. Accessed 6 June 2014.

Kalinowski ST, Wagner AP and Taper ML (2006). ML-Relate: a computer program for maximum likelihood estimation of relatedness and relationship. Mol. Ecol. Notes 6: 576-579. doi: 10.1111/j.1471-8286.2006.01256.x

Kalinowski ST, Taper ML and Marshall TC (2007). Revising how the computer program CERVUS accommodates genotyping error increases success in paternity assignment. Mol. Ecol. 16: 1099-1106.

Machado ABM, Drummond GM and Paglia AP (2008). Livro Vermelho da Fauna Brasileira Ameaçada de Extinção. Ministério do Meio Ambiente/Fundação Biodiversitas, Brasília.

Nicholls JA, Double MC, Rowell DM and Magrath RD (2000). The evolution of cooperative and pair breeding in thornbills Acanthiza (Pardalotidae). J. Avian Biol. 31: 165-176.

Raymond $\mathrm{M}$ and Rousset $\mathrm{F}$ (1995). GENEPOP (version 1.2): population genetics software for exact tests and ecumenicism. J. Heredity 86: 248-249. 